\title{
Arecoline suppresses HaCaT cell proliferation through cell cycle regulatory molecules
}

\author{
ZHONG-SU ZHOU ${ }^{1}$, MING LI $^{1,2}$, FENG GAO $^{3}$, JIE-YING PENG $^{2}$, HAI-BO XIAO $^{1}$, \\ LI-XIA DAI ${ }^{1}$, SHI-RONG LIN ${ }^{4}$, RUI ZHANG ${ }^{1}$ and LONG-YU JIN ${ }^{3}$ \\ ${ }^{1}$ Changsha Stomatological Hospital, Changsha, Hunan; ${ }^{2}$ Xiangya Hospital of Central South University, \\ Changsha, Hunan; ${ }^{3}$ The Third Xiangya Hospital of Central South University, Changsha, \\ Hunan, P.R. China; ${ }^{4}$ Taiwan Taipei Dental Sciences, Taipei, Taiwan, R.O.C.
}

Received November 19, 2012; Accepted January 14, 2013

DOI: $10.3892 /$ or.2013.2360

\begin{abstract}
Betel nut chewing is the most common cause of oral submucous fibrosis (OSF). Arecoline is the main component of the betel nut, and is associated with the occurrence and development of OSF through cytotoxicity, genotoxicity and DNA damage. Similar types of stimuli elicit differential responses in different cells. In the present study, we investigated the effects of arecoline on the $\mathrm{HaCaT}$ epithelial and $\mathrm{Hel}$ fibroblast cell lines. The data showed that arecoline affected HaCaT cell morphology. MTT assay revealed that arecoline suppressed $\mathrm{HaCaT}$ cell proliferation. Furthermore, we found that arecoline induced the cell cycle arrest of $\mathrm{HaCaT}$ cells. In comparison with the untreated control cells, following treatment with $\geq 75 \mu \mathrm{g} / \mathrm{ml}$ arecoline an increased percentage of $\mathrm{HaCaT}$ cells remained at the $\mathrm{G}_{0} / \mathrm{G}_{1}$ phase of the cell cycle, accompanied by a reduced percentage of cells in the $S$ phase. However, arecoline treatment did not significantly alter Hel cell cycle distribution. In the HaCaT epithelial cells, arecoline downregulated expression of the $\mathrm{G}_{1} / \mathrm{S}$ phase regulatory proteins cyclin D1, CDK4, CDK2, E2F1 as determined by reverse transcription-PCR analysis and western blotting. In summary, arecoline inhibits $\mathrm{HaCaT}$ epithelial cell proliferation and survival, in a dose-dependent manner, and cell cycle arrest in the $G_{1} / S$ phase, while this is not obvious in the Hel fibroblast cells. Potentially, our findings may aid in the prevention of arecoline-associated human OSF.
\end{abstract}

Correspondence to: Dr Long-Yu Jin, Department of Cardiothoracic Surgery, The Third Xiangya Hospital of Central South University, Tongzipo Road 138, Yuelu, Changsha, Hunan 410013, P.R. China E-mail: limcs51@gmail.com

Abbreviations: OSF, oral submucous fibrosis; MTT, 3-(4,5-dimethylthiazol-2-yl)-2,5-diphenyltetrazolium bromide; E2F1, E2F transcription factor 1; CDK4, cyclin-dependent kinase 4; CDK2, cyclindependent kinase 2

Key words: oral submucous fibrosis, proliferation, carcinogenesis, cell cycle

\section{Introduction}

Oral submucous fibrosis (OSF) is a chronic insidious disease predisposing to cancer. The rate of carcinoma incidence in OSF cases reaches up to $7.6 \%$. Areca nut (betel) chewing is one of the primary etiologic factors for OSF and carcinogenesis. The areca nut is indentified as a first class carcinogen by IARC $(1,2)$. Histologically, most OSF is characterized by epithelial atrophy and progressive accumulation of collagen fibers in the lamina propria while a minority is characterized by epithelial atypical hyperplasia. In tissues with OSF-associated carcinogenesis, both epithelial atrophy and atypical epithelia can exist or coexist. There is abnormal expression of proteins related to cell cycle arrest and apoptosis in OSF and in tissues showing carcinogenesis. The role and mechanism of arecoline in epithelial atrophy and epithelial hyperplasia require further investigation (3-10).

Eukaryotic cell division is a precise and orderly process with multi-factorial controls. The cell cycle can be divided into the four phases known as $\mathrm{G}_{1}, \mathrm{~S}, \mathrm{G}_{2}$ and $\mathrm{M}$, with two important restriction points. The restriction points are $\mathrm{G}_{1} / \mathrm{S}$ and $\mathrm{G}_{2} / \mathrm{M}$ phase, and only across these two limiting points can there be final completion of cell replication and division. Normal cells with DNA damage and cells affected by other external stimuli can undergo $G_{1} / S$ and/or $G_{2} / M$ phase blockage, delaying progression of the cell cycle. Yet, these normal cells win enough time to repair DNA damage before DNA replication and cell division (11). Cyclins and expression of cyclin-dependent-kinase (CDKs) form an active complex which positively regulates the cell cycle. CDK inhibitors (CKIs) combine with CDKs, and inhibit the activity of CDKs, thus playing a role as a negative regulator of the cell cycle. Cyclin D/CDK4/6 complexes are necessary to promote cell cycle through the $G_{1} / S$ phase restriction point. Cyclin $E$ and cyclin A further promote the phosphorylation of $\mathrm{Rb}$, induction of E2F1 in the intracellular accumulation, and promote a series of cyclins and cyclin-dependent protein kinases in the cell across the late $G_{1}$ phase to $S$ phase. The ultimate target of the $G_{2}$ checkpoint signaling pathway is the cyclin-dependent kinase (CDK) complex, CDK1-cyclin B1. Deregulation of cell cycle machinery is an important step in malignant transformation. Cyclin D1 is one of the most important proto-oncogenes 
Table I. Sequences of the primers for RT-PCR.

\begin{tabular}{|c|c|c|c|}
\hline Gene & Forward primer & Reverse primer & Product (bp) \\
\hline CDK2 & CCTGGAGATTCTGAGATTGA & GGGAAACTTGGCTTGTAAT & 113 \\
\hline CDK4 & GCATCCCAATGTTGTCCG & AGGCAGCCCAATCAGGTC & 499 \\
\hline Cyclin A & CCTGCGTTCACCATTCAT & ТСТТСТССТАСТТСААСТААСС & 383 \\
\hline Cyclin B & TTGGTTGATACTGCCTCTC & TCTGACTGCTTGCTCTTC & 204 \\
\hline Cyclin D1 & GAACAGAAGTGCGAGGAG & GCGGTAGTAGGACAGGAA & 477 \\
\hline Cyclin E & TGGATGTTGACTGCCTTG & TCTATGTCGCACCACTGA & 115 \\
\hline E2F1 & CACTGAATCTGACCACCAA & ACCATAACCATCTGCTCTG & 400 \\
\hline $\mathrm{CDC} 2$ & AGAGTTCTTCACAGAGACT & GGATGATTCAGTGCCATT & 488 \\
\hline$\beta$-actin & CCGTGACCTGACTGACTACCTC & ATACCGCAAGATTCCATACCC & 276 \\
\hline
\end{tabular}

RT-PCR, reverse transcription-PCR; CDK2, cyclin-dependent kinase 2; CDK4, cyclin-dependent kinase 4.

and cell cycle regulators. Its protein is known as cyclin D1 and is expressed in the $\mathrm{G}_{1}$ phase of the cell cycle $(12,13)$.

Similar types of stimuli elicit different responses in different cells. In the present study, we investigated the effects of arecoline on the $\mathrm{HaCaT}$ epithelial and Hel fibroblast cell lines. First, human keratinocyte cells of the HaCaT cell line and human embryo lung fibroblasts of the Hel cell line were treated with high doses of arecoline for a short time to observe the survival rate, cell cycle distribution and apotosis. Secondly, the molecular mechanism of epithelium atrophy induced by arecoline was studied.

\section{Materials and methods}

Cell lines. Keratinocytes of the naturally immortalized normal cell line, HaCaT, were obtained from the Laboratory of Apoptosis, College of Life Science, Hunan Normal University, China. The human embryonic lung fibroblast cell line (human normal fibroblast cell line), Hel, was established by the Laboratory of Molecular Virology, College of Life Science, Hunan Normal University, China (14).

Cell proliferation assay. The impact of arecoline treatment on cell proliferation was measured by the MTT assay as described previously (15). Briefly, keratinocytes from the natural immortalized normal cells, HaCaT, and human embryonic lung fibroblast cells, Hel, $\left(10^{4}\right.$ cells/well $)$ were cultured in triplicate with $10 \%$ FCS RPMI-1640 in 96-well plates in the presence or absence of $25,50,75,100$ and $125 \mu \mathrm{g} / \mathrm{ml}$ arecoline for 0 , 24,48 and $72 \mathrm{~h}$, respectively. The cells were then exposed to $5 \mathrm{mg} / \mathrm{ml} \mathrm{MTT}$ for $4 \mathrm{~h}$. The generated formazan was dissolved with dimethyl sulfoxide, and the absorbance was measured at $570 \mathrm{~nm}$ using an ELX-800 microplate reader (Bio Tek Instruments, Inc., Winooski, VT, USA).

Flow cytometric analysis of the cell cycle. The previously described keratinocytes and lung fibroblast cells were cultured in $10 \%$ FCS RPMI-1640 to $70 \%$ confluence and then treated with, or without, 25, 50, 75, 100 and $125 \mu \mathrm{g} / \mathrm{ml}$ arecoline for $12 \mathrm{~h}$, respectively. The adherent cells were trypsinized, harvested and fixed in $70 \%$ ethanol at $4^{\circ} \mathrm{C}$. Subsequently, the cells were washed with cold PBS and stained with propidium iodide (PI) in working solution $(0.5 \mathrm{mg} / \mathrm{ml} \mathrm{RNase,} \mathrm{and} 0.1 \mathrm{mg} /$ $\mathrm{ml} \mathrm{PI}$ in PBS). The cell cycle was characterized by flow cytometric analysis using a FACScan cytofluorimeter, and the data were analyzed by the CellQuest Pro Software (BectonDickinson, San Jose, CA. USA).

Reverse transcription-PCR analysis. Both cell lines were cultured in RPMI-1640 to $80 \%$ confluence and then treated with, or without, $25,50,75,100$ and $125 \mu \mathrm{g} / \mathrm{ml}$ arecoline for $12 \mathrm{~h}$, respectively. The cells were harvested, and their total RNA was extracted. One microgram total RNA was reversely transcripted into cDNA, as described previously $(15,16)$ and was subsequently used as the template for PCR reaction. The first step in the PCR reaction involved denaturing at $94^{\circ} \mathrm{C}$ for $5 \mathrm{~min}$, followed by 30 cycles of $94^{\circ} \mathrm{C}$ for $45 \mathrm{sec}, 55^{\circ} \mathrm{C}$ for $45 \mathrm{sec}$, and $72^{\circ} \mathrm{C}$ for $1 \mathrm{~min}$, followed by $72^{\circ} \mathrm{C}$ for $7 \mathrm{~min}$ for CDK2, CDK4, cyclin A, cyclin B, cyclin D1, cyclin E, E2F1 and $\mathrm{CDC} 2$. The primers $\mathrm{CDK} 2, \mathrm{CDK} 4$, cyclin $\mathrm{A}$, cyclin $\mathrm{B}$, cyclin D1, cyclin E, E2F1, CDC2 and $\beta$-actin were synthesized as shown in Table I. All RT-PCR reactions were repeated at least three times with varying cycle numbers to avoid potentially false results. $\beta$-actin was used as an endogenous control for normalization. The PCR products were analyzed by agarose-gel electrophoresis and ethidium bromide staining.

Western blotting. The ketatinocytes and the epithelial cells were cultured in RPMI-1640 up to $80 \%$ confluence and then treated with, or without, 25, 50, 75, 100 and $125 \mu \mathrm{g} / \mathrm{ml}$ arecoline for $12 \mathrm{~h}$, respectively. The cells were harvested and lysed in the lysis buffer [ $1 \%$ Nonidet P-40, $50 \mathrm{mM}$ Tris-HCl, pH 7.5, $50 \mathrm{mM}$ NaF, 2 mM EDTA, $400 \mathrm{mM} \mathrm{NaCl}, 10 \%$ glycerol plus complete protease inhibitor mixture (Roche Diagnostics)]. The protein concentrations were determined using the bicinchoninic acid protein assay kit (Pierce Chemical, Rockford, IL, USA). The cell lysates (50 $\mu \mathrm{g}$ ) from individual samples were separated by SDS-PAGE and transferred onto nitrocellulose membranes (HyClone Laboratories, Logan, UT, USA). The membranes were blocked with $5 \%$ nonfat milk in Trisbuffered saline/Tween-20 (25 mM Tris- $\mathrm{HCl}, 150 \mathrm{mM} \mathrm{NaCl}$, $\mathrm{pH} 7.5$, and $0.05 \%$ Tween-20) and probed with the primary antibody overnight at $4^{\circ} \mathrm{C}$. After washing with Tris-buffered saline/Tween-20 three times, the membranes were incubated 

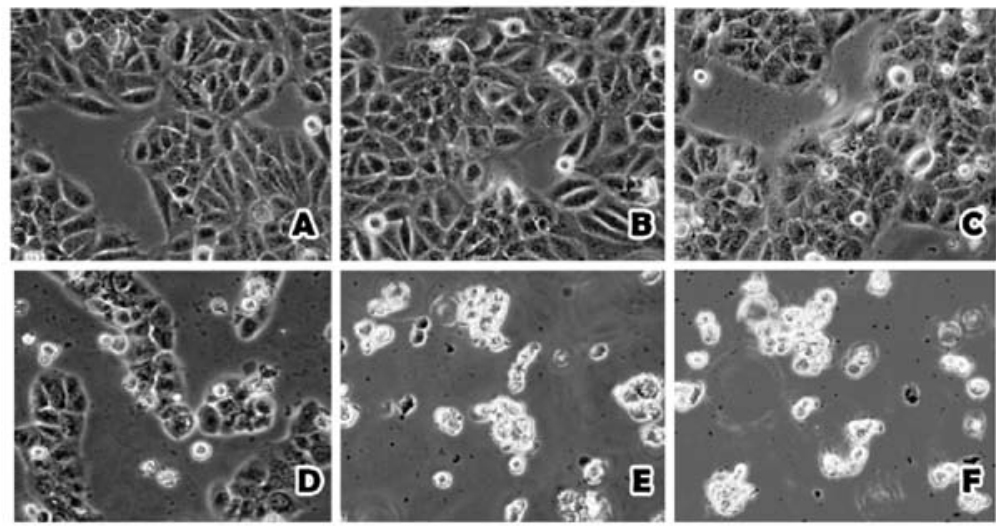

Figure 1. Arecoline affects the morphology of HaCaT epithelial cells, and promotes cell death in a dose-dependent manner. Concentrations of arecoline: (A) $0 \mu \mathrm{g} / \mathrm{ml}$, (B) $25 \mu \mathrm{g} / \mathrm{ml}$, (C) $50 \mu \mathrm{g} / \mathrm{ml}$, (D) $75 \mu \mathrm{g} / \mathrm{ml}$, (E) $100 \mu \mathrm{g} / \mathrm{ml}$ and (F) $125 \mu \mathrm{g} / \mathrm{ml}$ (magnification, $\mathrm{x} 100$ ).
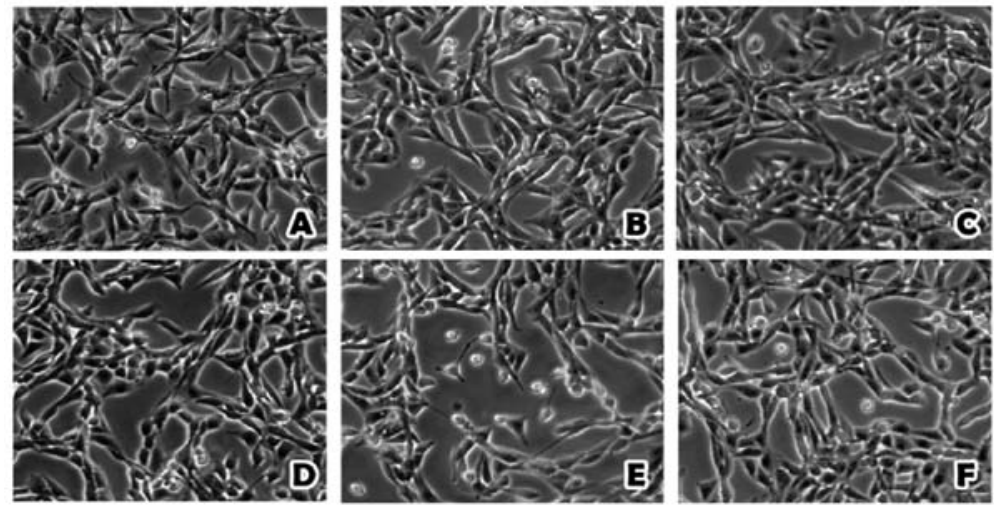

Figure 2. Effect of arecoline on the cell morphology of Hel cells. Concentrations of arecoline: (A) $0 \mu \mathrm{g} / \mathrm{ml}$, (B) $25 \mu \mathrm{g} / \mathrm{ml}$, (C) $50 \mu \mathrm{g} / \mathrm{ml}$, (D) $75 \mu \mathrm{g} / \mathrm{ml}$, (E) $100 \mu \mathrm{g} / \mathrm{ml}$ and (F) $125 \mu \mathrm{g} / \mathrm{ml}$ (magnification, $\mathrm{x} 100$ ).

with horseradish peroxidase-conjugated secondary antibodies (Santa Cruz Biotechnology, Inc., Santa Cruz, CA, USA), and the specific signals were visualized using ECL detection system. Antibodies against cyclin D1, CDK4, CDK2, E2F1, cyclin $\mathrm{B}, \mathrm{CDC} 2$, cyclin $\mathrm{A}$ and cyclin $\mathrm{E}$ were purchased from Cell Signaling Technology Inc. (Beverly, MA, USA).

Statistical analysis. Differences in nonparametric variables were analyzed by the Fisher's exact test using the EPI software (EPI Info, version 3.2.2, www.CDC.gov/epiinfo/). Differences in the quantitative variables between groups were analyzed by the Student's t-test using SPSS 11.0 program (SPSS, Chicago, IL, USA). A P-value $<0.05$ was considered to indicate a statistically significant result.

\section{Results}

Effect of arecoline on HaCaT cell morphology. The HaCaT cell morphology was significantly altered following treatment of arecoline at different concentrations after $48 \mathrm{~h}$. The outlines of the $\mathrm{HaCaT}$ cells were clear when treated with 0 and $25 \mu \mathrm{g} /$ $\mathrm{ml}$, but when the concentration of arecoline increased to $50 \mu \mathrm{g} /$ $\mathrm{ml}$, the boundaries of the $\mathrm{HaCaT}$ cells became indistinct and some of the cells were dead. There was massive cell death and a lack of boundaries between the cells when the concentration of arecoline was increased to 75, 100 and $125 \mu \mathrm{g} / \mathrm{ml}$ (Fig. 1). In contrast, the Hel cells were less affected by arecoline treatment. Only when the concentration of arecoline was increased to 100 and $125 \mu \mathrm{g} / \mathrm{ml}$, did the Hel cell morphology begin to change slightly (Fig. 2).

Arecoline suppresses HaCaT cell proliferation. To further test whether arecoline modulates $\mathrm{HaCaT}$ cell growth, $\mathrm{HaCaT}$ and Hel cells were treated with $0,25,50,75,100$ and $125 \mu \mathrm{g} / \mathrm{ml}$ arecoline, and their spontaneous proliferation was determined by MTT assays. Treatment with arecoline significantly inhibited the proliferation of $\mathrm{HaCaT}$ cells (Fig. 3A), but only slightly reduced Hel cell growth in vitro (Fig. 3B). Therefore, treatment with arecoline inhibited the proliferation of epithelial cells, but not fibroblasts in vitro.

Arecoline induces the cell cycle arrest of $\mathrm{HaCaT}$ cells. Inhibition of cell proliferation usually is mediated by inducing cell cycle arrest. To test this possibility, $\mathrm{HaCaT}$ and Hel cells were treated with $0,25,50,75,100$ and $125 \mu \mathrm{g} / \mathrm{ml}$ arecoline and the cell cycle distribution was determined by FACS analysis (Tables II and III). In comparison to the control cells without arecoline treatment, following treatment with $\geq 75 \mu \mathrm{g} / \mathrm{ml}$ 

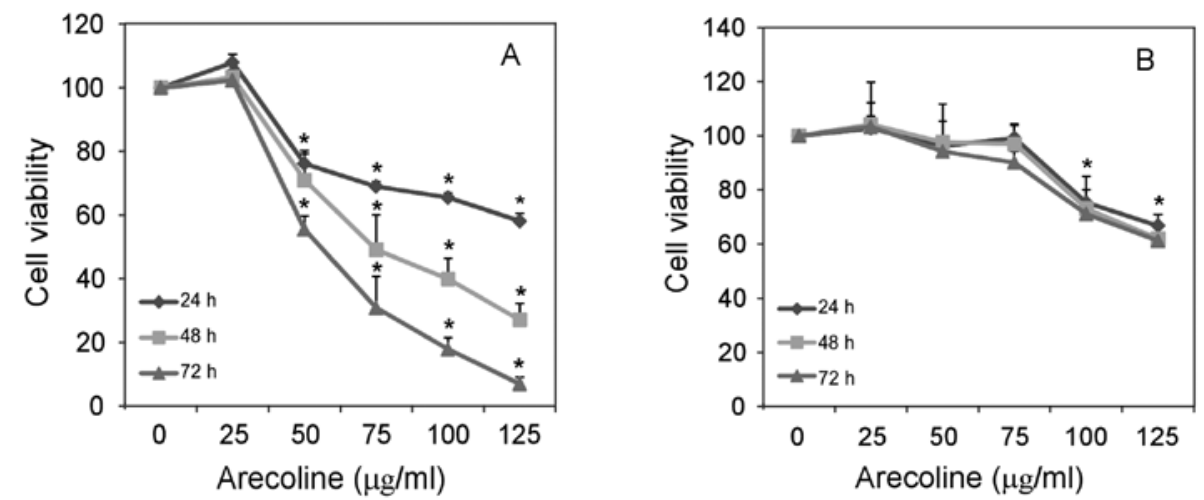

Figure 3. (A) Arecoline inhibits epithelial cell proliferation (HaCaT). (B) Effect of arecoline treatment on the viability of fibroblast cells (Hel).

Table II. Flow cytometric analysis of HaCaT cells following treatment with different concentrations of arecoline.

\begin{tabular}{lccc}
\hline & \multicolumn{2}{c}{ Phase of the cell cycle $^{\mathrm{a}}$} \\
\cline { 3 - 4 } Treatment & $\mathrm{G}_{0}-\mathrm{G}_{1}(\%)$ & $\mathrm{S}(\%)$ & $\mathrm{G}_{2}-\mathrm{M}(\%)$ \\
\hline Arecoline $(\mu \mathrm{g} / \mathrm{ml})$ & & & 18.93 \\
0 & 49.02 & 32.05 & 17.00 \\
25 & 51.06 & 31.94 & 15.69 \\
50 & 53.62 & 30.69 & 6.50 \\
75 & 73.00 & 20.50 & 3.16 \\
100 & 91.23 & 5.61 & 5.20 \\
125 & 89.67 & 5.13 & \\
\hline
\end{tabular}

${ }^{a}$ Numbers indicate the percentage of cells in the different phases of the cell cycle.

Table III. Flow cytometric analysis of Hel cells following treatment with different concentrations of arecoline.

\begin{tabular}{lccc}
\hline & \multicolumn{3}{c}{ Phase of the cell cycle $^{\mathrm{a}}$} \\
\cline { 3 - 4 } Treatment & $\mathrm{G}_{0}-\mathrm{G}_{1}(\%)$ & $\mathrm{S}(\%)$ & $\mathrm{G}_{2}-\mathrm{M}(\%)$ \\
\hline Arecoline $(\mu \mathrm{g} / \mathrm{ml})$ & & & 14.13 \\
0 & 52.52 & 33.35 & 16.89 \\
25 & 49.09 & 34.02 & 19.79 \\
50 & 50.04 & 30.17 & 18.04 \\
75 & 51.75 & 30.21 & 14.34 \\
100 & 54.02 & 31.64 & 14.22 \\
125 & 54.86 & 30.92 & \\
\hline
\end{tabular}

${ }^{\text {a} N u m b e r s ~ i n d i c a t e ~ t h e ~ p e r c e n t a g e ~ o f ~ c e l l s ~ i n ~ t h e ~ d i f f e r e n t ~ p h a s e s ~ o f ~ t h e ~ c e l l ~ c y c l e . ~}$

arecoline a higher percentage of $\mathrm{HaCaT}$ cells remained at the $\mathrm{G}_{0} / \mathrm{G}_{1}$ phase of the cell cycle (from 49.02 to $73.00 \%$ ) at $12 \mathrm{~h}$, accompanied by a reduced percentage of cells in the $\mathrm{S}$ phase (from 32.05 to $20.50 \%$ ). However, arecoline treatment did not significantly alter Hel cell cycling even after treatment with arecoline for $12 \mathrm{~h}$. Hence, these data demonstrate that arecoline treatment induces cell cycle arrest by inhibiting the $G_{1}$ to $\mathrm{S}$ phase transition of the cell cycle in epithelial cells in vitro.
Arecoline regulates the transcription level of cell cycle regulatory molecules in the HaCaT epithelial cells. To reveal the possible mechanism of the effect of arecoline on epithelial cells in vitro, the levels of mRNA transcripts of several cell cycle regulatory molecules (CDK2, CDK4, cyclin A, cyclin B, cyclin D1, cyclin E, E2F1, CDC2) were determined by semi-quantitative RT-PCR. Cyclin D1 mRNA expression was downregulated following arecoline stimulation, while 

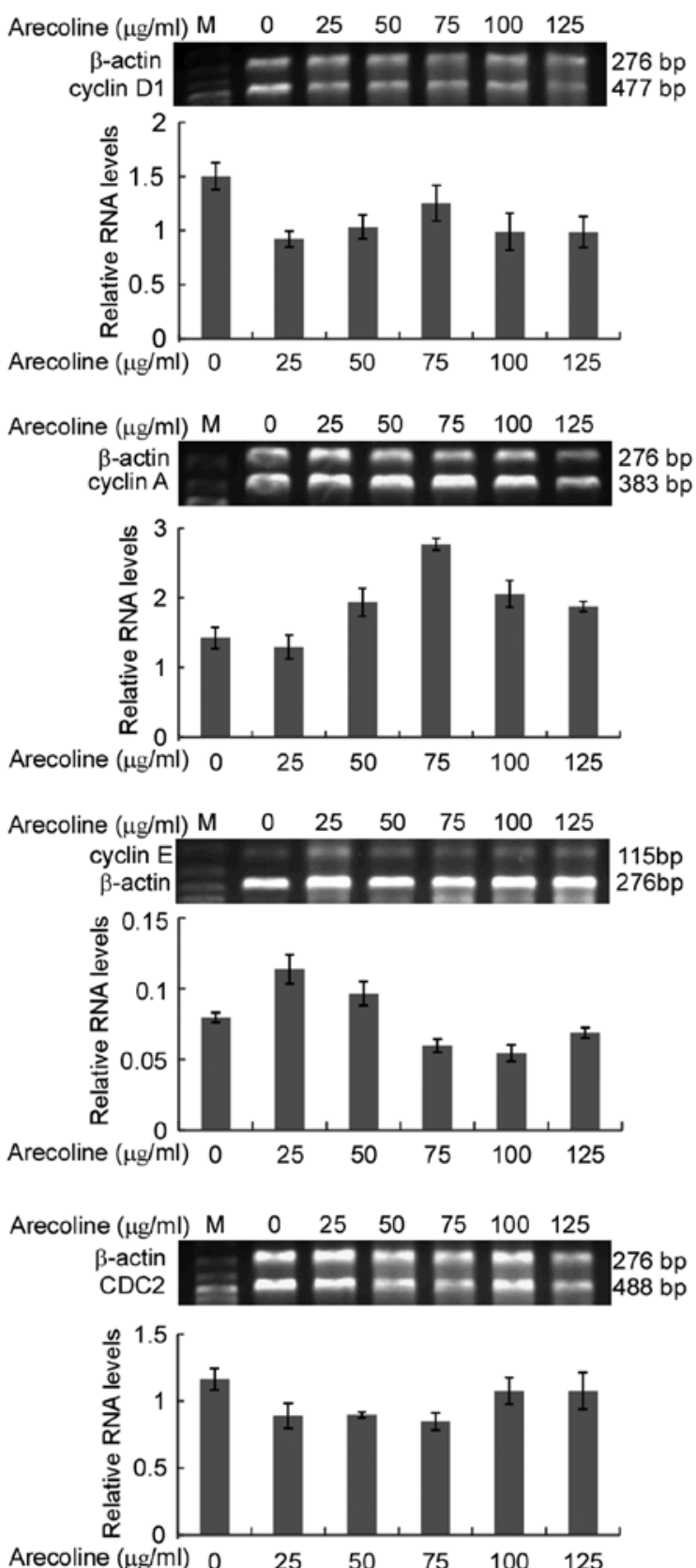

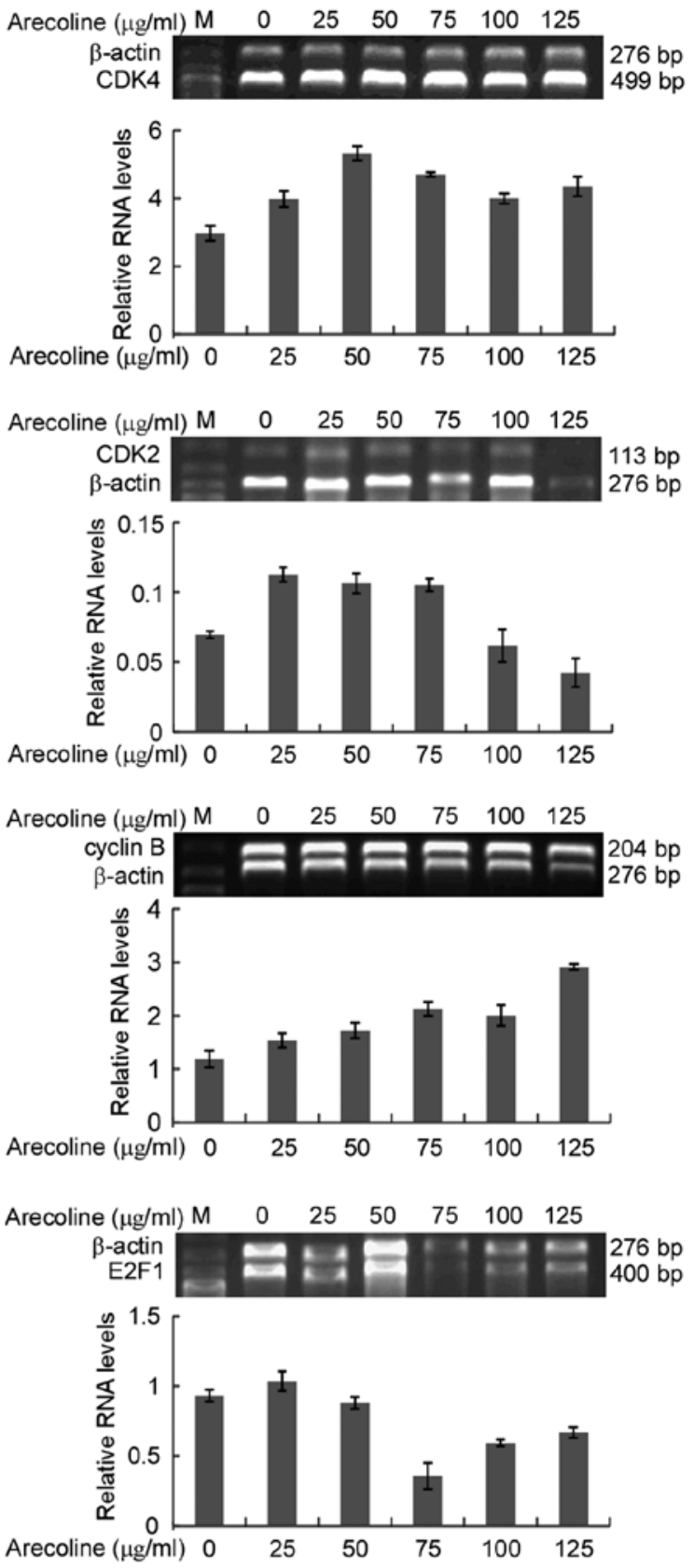

Figure 4. Arecoline regulates the transcription level of cell cycle regulatory molecules in the epithelial HaCaT cells.

there was no significant concentration gradient dependence. The mRNA expression of cyclin B was upregulated. Low concentrations of arecoline stimulated CDK4 expression. However, its expression was suppressed following treatment with high concentrations of arecoline. Cyclin A expression level was increased in the $\mathrm{HaCaT}$ cells following treatment with arecoline. Cyclin E expression level was decreased with an increase in arecoline concentrations. CDK2 had the same tendency as cyclin E. There was no significant difference in CDC2 levels (Fig. 4).

Arecoline regulates the protein levels of cell cycle regulatory molecules in the HaCaT epithelial cells. To confirm the change mechanism of cell cycle regulatory molecules, we tested the protein levels of CDK2, CDK4, cyclin A, cyclin B, cyclin D1, cyclin E, E2F1 and CDC2 by western blotting. The expression levels of cyclin D1, CDK4, CDK2 and E2F1 were significantly downregulated. Expression of cyclin A and cyclin E was slightly upregulated in $\mathrm{HaCaT}$ cells following arecoline stimulation. There was no significant difference in cyclin B and CDC2 expression (Fig. 5).

\section{Discussion}

Betel nut chewing is the most common cause of OSF. Arecoline is the main component of the betel nut, and it is associated with the occurrence and development of OSF through cytotoxicity, genotoxicity and DNA damage. Arecoline inhibits oral keratinocytes and vascular endothelial cell growth $(17,18)$. However, using identical arecoline stimulation, OSF epithelial tissues 


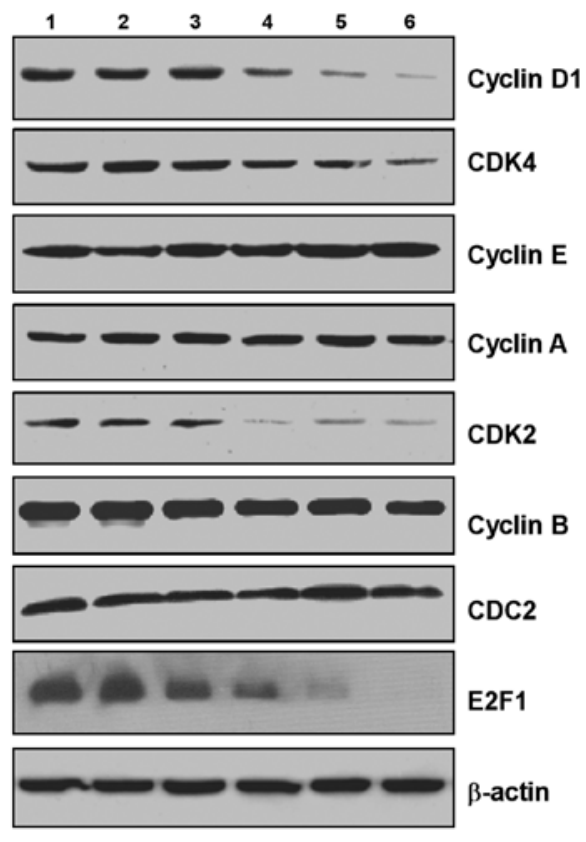

Figure 5. Arecoline affects the protein expression level of cell cycle regulatory molecules in $\mathrm{HaCaT}$ epithelial cells. Lane $1,0 \mu \mathrm{g} / \mathrm{ml}$ arecoline; lane 2, $25 \mu \mathrm{g} / \mathrm{ml} ;$ lane 3, $50 \mu \mathrm{g} / \mathrm{ml} ;$ lane 4, $75 \mu \mathrm{g} / \mathrm{ml}$; lane 5, $100 \mu \mathrm{g} / \mathrm{ml}$; lane 6, $125 \mu \mathrm{g} / \mathrm{ml}$.

became atrophic and presented vascular occlusion, and showed the beginning of the accumulation of fibroblasts and collagen fibers. Similar types of stimuli elicit differential responses in different cell types. In the present study, we studied the effects of arecoline on $\mathrm{HaCaT}$ epithelial cells and Hel fibroblasts.

Our data demonstrated the effects of arecoline on HaCaT cell morphology. The cell morphologies were significantly different dependent on the arecoline concentration after $48 \mathrm{~h}$ of treatment. In contrast, the Hel cells showed no effects following arecoline treatment. MTT assay revealed that arecoline suppressed $\mathrm{HaCaT}$ cell proliferation. Treatment with arecoline significantly inhibited the proliferation of $\mathrm{HaCaT}$ cells, but only slightly reduced Hel cell growth in vitro. Therefore, treatment with arecoline inhibited the proliferation of epithelial cells, but not fibroblasts, in vitro. Our results confirmed our hypothesis: different cells have differential responses to similar types of stimuli.

Cell cycle checkpoints are biochemical pathways that ensure the orderly and timely progression and completion of critical events, such as DNA replication and chromosome segregation $(9,19)$. In the present study, we found that arecoline induced $\mathrm{HaCaT}$ cell cycle arrest. In comparison with control cells without arecoline treatment, following treatment with $\geq 75 \mu \mathrm{g} / \mathrm{ml}$ arecoline a higher percentage of HaCaT cells remained at the $G_{0} / G_{1}$ phase of the cell cycle, accompanied by a reduced percentage of cells in the $S$ phase. However, arecoline treatment did not significantly alter Hel cell cycling. Huang et al (13) found that arecoline decreased interleukin-6 production and induced apoptosis and cell cycle arrest in human basal cell carcinoma cells. Arecoline, a major alkaloid of the areca nut, was found to inhibit p53, repress DNA repair, and trigger DNA damage response in human epithelial cells (21). Cyclin D1 expression and its possible regulation in chewing tobacco have been shown to mediate oral squamous cell carcinoma progression (22).

To reveal the possible mechanism of arecoline effect on epithelial cells in vitro, the levels of mRNA transcripts of cell cycle regulatory molecules were determined by semi-quantitative RT-PCR and western blotting. Short-term high-dose arecoline exerted little effect on Hel fibroblast cell growth, but significantly inhibited $\mathrm{HaCaT}$ epithelial cell growth and arrested $\mathrm{HaCaT}$ cells at the $\mathrm{G}_{1} / \mathrm{S}$ phase, which was mainly through decreased protein expression and gene transcription of cyclin D1, CDK4, CDK2, E2F1, but had no obvious effects on cyclin $B / C D C 2$ which is related to the $G_{2} / M$ phase. Thus, epithelial atrophy in OSF is mainly attibuted to cell cycle arrest and imbalance of proliferation and apoptosis induced by arecoline. Studies have shown that expression of the transcription factor E2F1 was increased in tumors and proliferative diseases $(11,17,18,23-25)$. When cells cross the $G_{1} / S$ restriction point, the cell cycle path becomes irreversible with autonomy until the end of the cell cycle (26-29). Arecoline had no significant effect on fibroblasts in the $\mathrm{G}_{1} / \mathrm{S}$ phase, which may explain the reasons for subcutaneous fibroblast proliferation-induced submucosa collagen accumulation $(28,29)$.

In summary, arecoline inhibits HaCaT epithelial cell proliferation and survival, in a dose-dependent manner with cell cycle arrest in the $G_{1} / S$ phase, while this observation is not obvious in Hel fibroblast cells. Arecoline downregulates the expression of $G_{1} / S$ phase regulatory proteins cyclin D1, CDK4, CDK2 and E2F1 in HaCaT epithelial cells. Potentially, our findings may aid in the prevention of arecoline-associated human OSF.

\section{Acknowledgements}

The study was supported by the International Cooperation Program Funds of the China Hunan Provincial Science and Technology Department (project no. 2012WK4005) and the Research Programe from the Science and Technology Department of Hunan Province, China (project no. 2012FJ4076). We would like to thank Dr Fred Bogott for his excellent English editing of the manuscript.

\section{References}

1. Chaturvedi P, Vaishampayan SS, Nair S, et al: Oral squamous cell carcinoma arising in background of oral submucous fibrosis: A clinicopathologically distinct disease. Head Neck: Sep 13, 2012 (Epub ahead of print). doi: 10.1002/hed.23143.

2. Mehrotra D, Kumar S, Agarwal GG, Asthana A and Kumar S: Odds ratio of risk factors for oral submucous fibrosis in a case control model. Br J Oral Maxillofac Surg: Aug 27, 2012 (Epub ahead of print).

3. Khan S, Chatra L, Prashanth SK, Veena KM and Rao PK: Pathogenesis of oral submucous fibrosis. J Cancer Res Ther 8: 199-203, 2012.

4. Kothari MC, Hallur N, Sikkerimath B, Gudi S and Kothari CR: Coronoidectomy, masticatory myotomy and buccal fat pad graft in management of advanced oral submucous fibrosis. Int J Oral Maxillofac Surg 41: 1416-1421, 2012.

5. Ranganathan $\mathrm{K}$ and Kavitha R: Proliferation and apoptosis markers in oral submucous fibrosis. J Oral Maxillofac Pathol 15: 148-153, 2011.

6. Khan I, Agarwal P, Thangjam GS, Radhesh R, Rao SG and Kondaiah P: Role of TGF- $\beta$ and BMP7 in the pathogenesis of oral submucous fibrosis. Growth Factors 29: 119-127, 2011. 
7. Tadakamadla J, Kumar S and Mamatha GP: Evaluation of serum copper and iron levels among oral submucous fibrosis patients. Med Oral Patol Oral Cir Bucal 16: e870-e873, 2011

8. Wang YC, Tsai YS, Huang JL, et al: Arecoline arrests cells at prometaphase by deregulating mitotic spindle assembly and spindle assembly checkpoint: implication for carcinogenesis. Oral Oncol 46: 255-262, 2010.

9. Lee PH, Chang MC, Chang WH, et al: Prolonged exposure to arecoline arrested human KB epithelial cell growth: regulatory mechanisms of cell cycle and apoptosis. Toxicology 220: $81-89$, 2006.

10. Lu SY, Chang KW, Liu CJ, Tseng YH, Lu HH, Lee SY and Lin SC: Ripe areca nut extract induces $\mathrm{G}_{1}$ phase arrests and senescence-associated phenotypes in normal human oral keratinocyte. Carcinogenesis 27: 1273-1284, 2006.

11. Tu HF, Liu CJ, Chang CS, Lui MT, Kao SY, Chang CP and Liu TY: The functional $(-11715 \mathrm{~A} \rightarrow 6 \mathrm{~A})$ polymorphisms of matrix metalloproteinase 3 gene as a risk factor for oral submucous fibrosis among male areca users. J Oral Pathol Med 35: 99-103, 2006

12. Chiu CJ, Chiang CP, Chang ML, et al: Association between genetic polymorphism of tumor necrosis factor-alpha and risk of oral submucous fibrosis, a pre-cancerous condition of oral cancer. J Dent Res 80: 2055-2059, 2001

13. Huang LW, Hsieh BS, Cheng HL, Hu YC, Chang WT and Chang KL: Arecoline decreases interleukin-6 production and induces apoptosis and cell cycle arrest in human basal cell carcinoma cells. Toxicol Appl Pharmacol 258: 199-207, 2012.

14. Tsai YS, Lee KW, Huang JL, et al: Arecoline, a major alkaloid of areca nut, inhibits p53, represses DNA repair, and triggers DNA damage response in human epithelial cells. Toxicology 249: 230-237, 2008

15. Mishra R and Das BR: Cyclin D1 expression and its possible regulation in chewing tobacco mediated oral squamous cell carcinoma progression. Arch Oral Biol 54: 917-923, 2009.

16. Liu L, Xie H, Chen X, Shi W, Xiao X, Lei D and Li J: Differential response of normal human epidermal keratinocytes and HaCaT cells to hydrogen peroxide-induced oxidative stress. Clin Exp Dermatol 37: 772-780, 2012.
17. Zhou Y, Zeng Z, Zhang W, et al: Lactotransferrin: a candidate tumor suppressor-Deficient expression in human nasopharyngeal carcinoma and inhibition of NPC cell proliferation by modulating the mitogen-activated protein kinase pathway. Int J Cancer 123: 2065-2072, 2008.

18. Zhou Y, Zeng Z, Zhang W, et al: Identification of candidate molecular markers of nasopharyngeal carcinoma by microarray analysis of subtracted cDNA libraries constructed by suppression subtractive hybridization. Eur J Cancer Prev 17: 561-571, 2008.

19. Kuo FC, Wu DC, Yuan SS, et al: Effects of arecoline in relaxing human umbilical vessels and inhibiting endothelial cell growth. J Perinat Med 33: 399-405, 2005.

20. Bartek J, Lukas J and Bartkova J: Perspective: defects in cell cycle control and cancer. J Pathol 187: 95-99, 1999.

21. Malumbres M: Cyclins and related kinases in cancer cells. J BUON 12 (Suppl 1): S45-S52, 2007.

22. van den Heuvel S: Cell-cycle regulation. WormBook 1-16, 2005.

23. Chen HZ, Tsai SY and Leone G: Emerging roles of E2Fs in cancer: an exit from cell cycle control. Nat Rev Cancer 9: 785-797, 2009.

24. Kwong RA, Nguyen TV, Bova RJ, et al: Overexpression of E2F-1 is associated with increased disease-free survival in squamous cell carcinoma of the anterior tongue. Clin Cancer Res 9: 3705-3711, 2003.

25. Luo X, Pan Q, Liu L, et al: Genomic and proteomic profiling II comparative assessment of gene expression profiles in leiomyomas, keloids and surgically-induced scars. Reprod Biol Endocrinol 5: 35, 2007.

26. Calonge TM and $\mathrm{O}^{\prime}$ Connell MJ: Turning off the $\mathrm{G}_{2}$ DNA damage checkpoint. DNA Repair 7: 136-140, 2008.

27. Miyazaki T and Arai S: Two distinct controls of mitotic cdk1/cyclin B1 activity requisite for cell growth prior to cell division. Cell Cycle 6: 1419-1425, 2007.

28. Yu Y, Kovacevic Z and Richardson DR: Tuning cell cycle regulation with an iron key. Cell Cycle 6: 1982-1994, 2007.

29. Nakayama KI and Nakayama K: Ubiquitin ligases: cell-cycle control and cancer. Nat Rev Cancer 6: 369-381, 2006. 